\title{
Wetland River Flow Interaction in a Sedimentary Formation of the White Volta Basin of Ghana
}

\author{
Benjamin Kofi Nyarko \\ Correspondence: Dept of Geography \& Regional Planning, University of Cape Coast, Ghana. E-mail: \\ bnyarko@ucc.edu.gh
}

Received: June 17, 2019

Accepted: November 13, 2019

Online Published: January 4, 2020

doi:10.5539/esr.v9n1p15

URL: https://doi.org/10.5539/esr.v9n1p15

\begin{abstract}
Groundwater resources in the floodplain wetlands of the White Volta River basin of Ghana is a major source of water for irrigation activities of communities living around and baseflow to sustain the flow of the river. Hydrology of the floodplain wetlands in the basin is complex, characterized by temporally variable storage volumes with erratic contribution to streamflow. For the continual usage of groundwater resources in the floodplains there is a need to study the form of interaction between the main river and floodplain wetlands. The study, adopted the PM-WIN (MODFLOW) model for simulating the interaction between the wetland and stream. Additionally, the lower boundary discharge output from the HYDRUS-1D model is the estimated recharge. This input quantifies the temporal and spatial variations in sub-surfaces discharges in the floodplain wetland. The simulation of the sub-surface hydraulic head of the wetland indicates a systematic variation relative to the White Volta River response to changes in the rainfall pattern. The interaction conditions vary from season to season with March, April, and May showing the least leakage (estimated values of $0.03 \mathrm{~mm} /$ day, $0.06 \mathrm{~mm} /$ day, and $0.15 \mathrm{~mm} /$ day, respectively) from the river into the floodplain wetland. Notably, the interaction between the wetland and the river as simulated is bidirectional. With most of the flow coming out from the river into the floodplain wetland, this condition persists in the months of August and September.
\end{abstract}

\section{Introduction}

Rivers are not only an extension or continuum of groundwater and surface waterflow, but they also serve as a critical component of the riparian and riverine ecology (Woessner, 2000). Existence of any river system is due to the integration of all flow sources, and connectivity of spatially individual components. The riparian areas consisting of floodplain wetlands contribute to the direction of hydrological flows, but its connectivity to the main channel depend on the lithology, geology and landscape settings (Grape et al., 2006; Brooks, 2005). Floodplains wetlands in peak flows gets inundated and provides a lot of environmental benefits and services such as habitat for wildlife, water purification, groundwater recharge and production of biomass (Bridge 2005). These benefits emanate from the cumulative effects of heterogeneity of hydrological connections. Wetlands in different geological formation and landscape setting, provides important ecosystem services but lacks sufficient scientific data on its behavior, distribution, types and functions to support any meaningful decision making by institution involve in environmental and water resources management (Dixon et al., 2016). To deal with problems related to floodplain wetlands and services it provides, earth scientist, civil and agricultural engineers must understand its connections with rivers (Bridge, 2005).

Processes within floodplain wetlands are governed by the regional flow process and nature of the landscapes, they also have a spatial and temporal complex hydrological interaction with it surrounding (Mansel et al., 2000) 1997). The level of connectivity may be through persistent but slow flow subsurface pathways in sedimentary formation or fast process of runoff generation. Nicola (2005) works within the sedimentary formation of the Volta River basin, noted low level of hydraulic heads in the aquifers vis-à-vis flows and attributed it to reduced recharge process.

Floodplain wetlands (FPW) are highly connected to river networks through surface water, shallow groundwater, and biological activities. The effects of wetlands on rivers are a function of the magnitude of floodwaters, geomorphic structure of the FPW, and its proximity to the channel (Lang et al 2012; Brooks, 2005). The absence of surface connections from FPW to rivers might lead to restrictions of material exchange with its attended consequence on water quality (Ameli and Creed, 2017). Lang et al 2012 found out that rivers interact with the floodplain wetland in three ways: 1) through direct surface runoff, 2) through sub-surface water flow, and 3) losing water to wetlands by seepage through the river walls. The interaction between floodplain wetlands and a river sometimes vary, over a very short time frame or distance in response to rapid rises in river stage due to storm runoff. For instance the high water level in the White Volta 
River as in 1994 and 2007 was enough to overflow the banks causing a widespread surface recharge. Studies in wetland hydrology tend to develop water budget or describe the wetland water table (Owen, 1995; Cooper et al., 1998) as a way to demonstrate the interaction between ecology and hydrology (Drexler et al., 1999).

As competing demand for wetland water resources within the White Volta River basin for agriculture and ecological activities are on the ascendency, studies (Ferdnald et al, 2001; Grapes et al., 2006) do not represent variability in wetland hydrological process and interaction with river system. From available literature (US-EPA, 2015), the influence floodplain wetlands has on rivers have been generalized, information on their level of connectivity and function is needed to understand frequency, duration, magnitude, timing, or rate of change. In the White Volta Basin, scientist inability to quantify the hydrologic connection between wetland and river flow in different geological formations remains a challenge and undermines our knowledge and understanding of the systematic variation of flow within a changing environment. Also no physical base model has been used to capture wetland-river connectivity in the basin in order to map out subsurface connectivity. Additionally, to enable managers of the basin compare the spatio-temporal characteristic of the wetland. This paper discusses processes involved in the use of PM-WIN (MODFLOW), to determine forms of interaction between the main White Volta River and the basin floodplain wetlands. The study is sectioned into three main parts: 1) an overview of the model; 2) discussion of the setting of the MODFLOW model, indicating the input data used; 3) discussion of model results and sensitivity analysis. This study is to fill gap in science by using numerical models to quantify and understand the connectivity and direction of flow between wetland and river flow in a sedimentary formation of a tropical system to inform management practices.

\subsection{Theoretical Background}

Hydrology of a river system is controlled by a broad continuum of free surface and subsurface hydrologic connecting flow paths (Winter, 2001; Wolock et al., 2004; Devito et al., 2005; Poole et al., 2006; Wagener et al., 2007; Poole, 2010; Bencala et al., 2011; Jencso and McGlynn, 2011). Knowledge of basic wetland surface water- groundwater-river network interaction is to understand their level of connectivity. At the broadest scale, regional climate interacts with river-basin terrain and geology to shape inherent hydrologic infrastructure that bounds the nature of basin hydrologic flow paths.

Groundwater and surface water system in floodplain environment are not isolated components of the hydrological cycle, but instead interact in a variety of physiographic and climatic landscapes. Understanding the basic principles of modelling interaction between groundwater and surface water is essential for efficient and effective water resources management. Modelling wetland hydrodynamics a fundamental consideration should be given to the physics of surface flow processes (Grapes et al., 2005). Water flow in wetlands can be represented by an overall water movement often dominated slough channel flow, i.e., flow through a network of open water channels that exist between areas or patches of dense vegetation (Lewandowski 1993).

Groundwater modelling is a multifaceted task by which greater understanding of the physical, chemical and biological condition in the subsurface can be achieved. Groundwater and surface water interaction models are analytical tools for characterisation and prediction of the quantity and quality of groundwater. In attempting to understand ground water and surface water interaction most research has been on the vertical interaction of surface and groundwater. For instance, Nield et al. (1994) used a numerical model to examine groundwater flow in vertical sections near surface water bodies, such as lakes, wetlands, ponds, rivers, canals, and drainage and irrigation channels. They distinguished different flow regimes by noting the presence and nature of groundwater mounds or depressions near the edges of a surface water body and by corresponding stagnation points. Matos et al. (2002) examined aquifer heterogeneity and channel pattern on flow interactions between stream and groundwater systems. In such a study, MODFLOW, was employed, to evaluate the magnitude, direction and spatial distribution of stream-subsurface exchange flows, with the underlying sediments acting as an aquifer. FLOWNET, FEFLOW, MIKE-SHE and other numerical models have been used to plot and visualize equal hydraulic heads and groundwater flow paths and mostly consist of equipotential lines and flow streamlines. Physical-based, process-oriented and spatially distributed models have seldom been applied to study wetlands in developing countries, since they are complex to operate and require a level of data that is hardly available in most developing countries because of cost (Bonell and Balek 1993).

Modeling of floodplain wetland and river interaction is both numerically and theoretically demanding and requires solving complicated numerical approximations to differential equations (Bockelmann et al. 2004; Fischer-Antze et al. 2001; Wu et al. 2000). In most cases wetlands are generally incorporated in groundwater models as general head boundary nodes even though they can be used as constant heads (Restropo et al. 1998). The hydrologic regime of floodplain wetlands depends on the varying degree of flow in the main channel, making wetlands vulnerable to hydrologic changes resulting from flow regulation (Reid and Quinn 2004; Cloke at al. 2006). However, the nonlinear interactions among recharge, discharge, boundary conditions and changes in groundwater storage makes the solving of problems relating to recharge and groundwater development difficult, making system parameters and their geographical distribution 
unaccounted for (Sanford 2002).

PM-WIN (MODFLOW) a model employed in this work has the capabilities to simulate many of the features influencing the in-field water regime, including anisotropy and heterogeneity in hydraulic properties. In modeling floodplain wetland river flow interaction at the Pwalugu site PM-WIN (MODFLOW) was employed (Chaing and Kinzelbach 1998) for the following reasons:

- MODFLOW takes account of spatial heterogeneities, vertical groundwater flow and any regional groundwater flow component.

- Leakages through heavy soils can occur at low rates and consequently become a minor component at the field scale, although the volume of leakage can be significant over the total area of the wetland.

- Irregular field boundaries and steep hydraulic gradients to the river are accommodated.

- Recharge can be distributed spatially, and recharge is assumed to be added instantaneously to the saturated zone.

- MODFLOW allows evaporation from the soil surface, hence the maximum evaporation rate is assigned to each cell when the water table equals an assigned head value and ceases below the assigned extinction depth.

- The PMWIN model is free.

\section{Study Area}

The study site is within the Savanna belt and its climate (Figure 1.1) is classified as semi-arid type, that is influenced by three air masses Eastern continental (E), Tropical maritime (mT) and Tropical continental (cT) air masses (Figure 1). The air masses interaction depends on the oscillation of the inter-tropical convergence zone (ITCZ). At a point in time, the influence of $\mathrm{mT}$ or cT determines the characteristics of the weather. The cT winds are dry and dusty that is mostly experienced within the months of November to April that is the dry seasons, Temperature within these months ranges between $20^{\circ} \mathrm{C}$ to $34^{\circ} \mathrm{C}$. The $\mathrm{mT}$ felt mostly in the wet season between March and October, exhibiting a high rate of humidity ranging from $60 \%$ to $90 \%$ at $0600 \mathrm{hrs}$ and $77 \%$ to $78 \%$ at

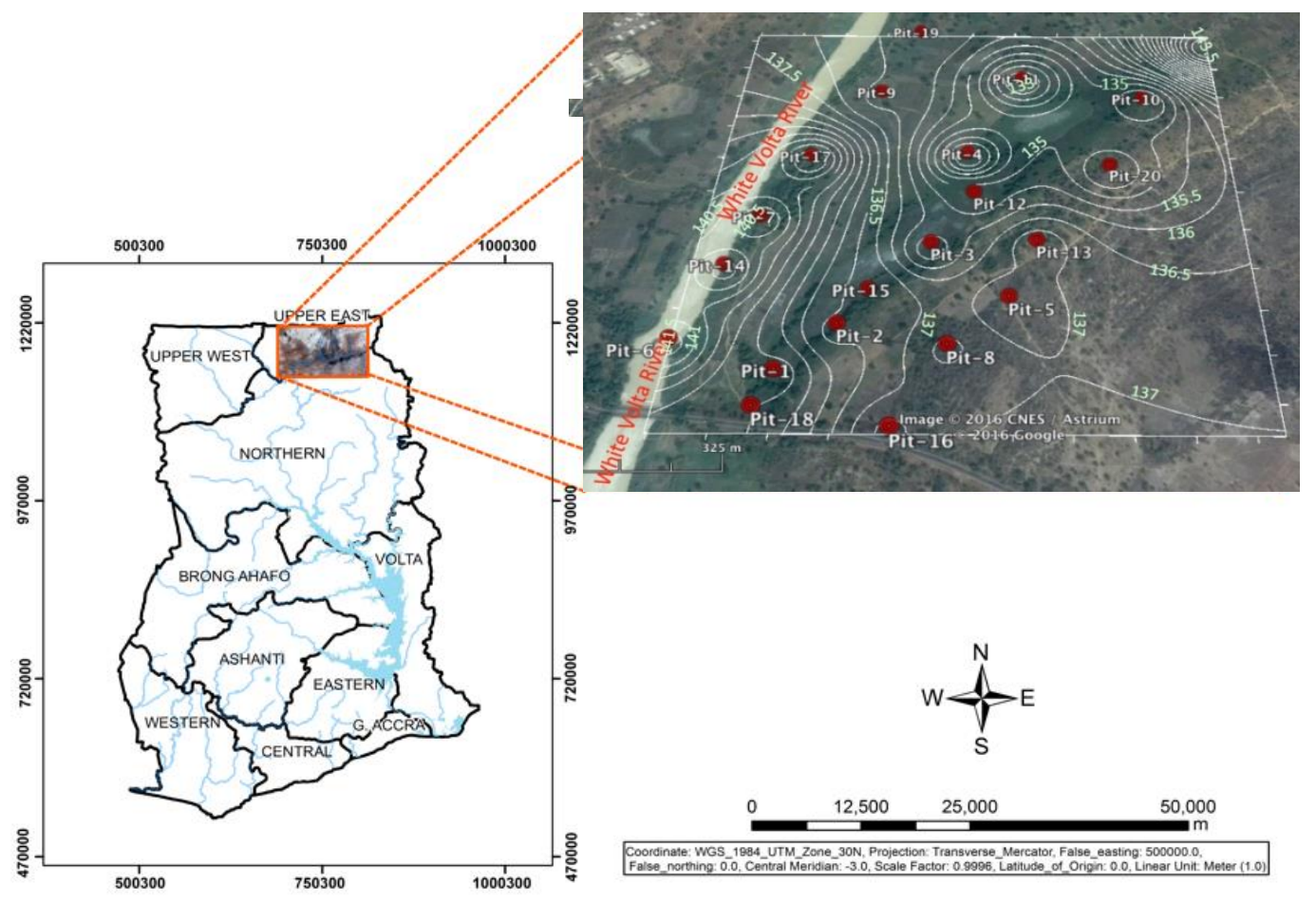

Figure 1.1. Map indicating the Pwalugu Study Site

\subsection{Geological Settings}

The basement rock underlying the catchment is the Voltaian, Birimian and Granitiods formation (Kesse, 1985). Voltaian system consists of limestone, arkose quartzite, conglomerate, sandstone, and shale (Figure 1.2). The Birimian system consists of greywacke, metamorphosed lava, tuff, pyroclastic rock, and. Schist. Faulting in this system tends to follow the folds. Joints in the rocks have different orientation but are mostly parallel to the folds. The Granitiods are 
mostly of the Bongo and Cape Coast series. The Bongo Granitiods consist of prophyritic hornblende, microdine granite, while the Cape Coast series is made up of muscovite-biotite, granite and potash rich. The Voltaian systems are well consolidated and are not inherently permeable except in a few areas. The stratigraphic classification of these sediments have been difficult due largely to

- Apparent lack of fossils in the sediments as only some decorticated fragments of plants and worm-tracks are observed.

- Lateral facies changes and overlaps resulting from movements during deposition.

Soils found within the Volta River catchment are grouped as those derived from sandstones, schist, granites, alluvial materials, greenstone, andesite, and amphibolities. Specifically the soils found in the study site are Eutric Fluvisol, Lithic Leptosols, Eutric Gleysols and Gleyic Lixisols,. Soil texture at study site consists of clay, silty clay, loamy clay and sandy clay. Soils profile of the wetland in the sedimentary formation (Table 1.1) can be distinguished using their properties and types of horizons. Soils in the Pwalugu wetland sites have distinct horizons, that is A and B horizons. Soil moisture content (Figure 1.2) varies in the study sites, with high moisture content at the depth of $100 \mathrm{~cm}$, which might be due to capillarity.

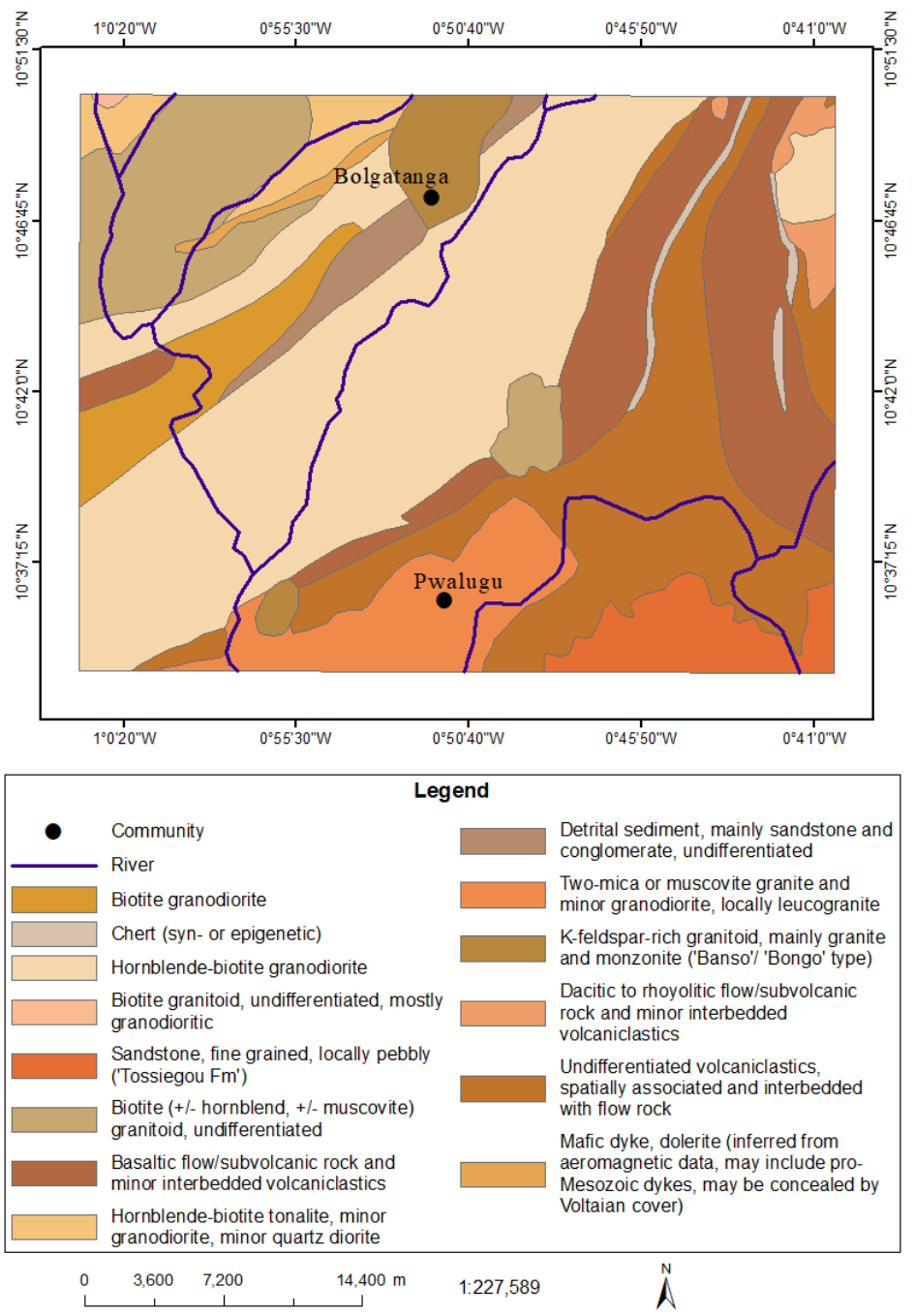

Figure 1.2. Geology of the study area 
Table 1.1. Soil horizon description at Pwalugu wetland site

\begin{tabular}{c|c|c|c|c|c|c|c|c}
\hline Horizon & Depth & Color & $\begin{array}{c}\text { Field } \\
\text { texture }\end{array}$ & Structure & Concretion & Mottle & $\begin{array}{c}\text { Mottle } \\
\text { color }\end{array}$ & $\begin{array}{c}\text { Root } \\
\text { Density }\end{array}$ \\
\hline A & 20 & $\begin{array}{c}\text { Very dark } \\
\text { grayish } \\
\text { brown }\end{array}$ & Silty loam & $\begin{array}{c}\text { Strong and } \\
\text { medium } \\
\text { angular } \\
\text { block }\end{array}$ & - & - & - & Abundant \\
\hline B1 & 50 & $\begin{array}{c}\text { Dark } \\
\text { yellowish } \\
\text { brown }\end{array}$ & Clay & $\begin{array}{c}\text { Strong and } \\
\text { medium } \\
\text { angular } \\
\text { block }\end{array}$ & - & Few & - & common \\
\hline B2 & 80 & $\begin{array}{c}\text { Yellowish } \\
\text { brown }\end{array}$ & Clay loam & $\begin{array}{c}\text { Strong and } \\
\text { medium } \\
\text { angular } \\
\text { block }\end{array}$ \\
B2 & 100 & $\begin{array}{c}\text { Brownish } \\
\text { yellow }\end{array}$ & Clay loam & $\begin{array}{c}\text { Strong and } \\
\text { medium } \\
\text { angular } \\
\text { block }\end{array}$ & - & Few & - & Very few \\
\hline
\end{tabular}

\section{Materials and Methods}

\subsection{Data Collection}

Data collected to run the MODFLOW model was done using field measurement, field observation and laboratory analysis. The field data collection involved measurement of soil infiltration, hydraulic conductivity, and river cross-sections. Field observations were undertaken to attain a level of generality by locating common factors such as water logging and other topographic parameters. This was carried out for quick and appropriate predictions in areas where detailed installation of equipment is not required (De Vans, 1993; Molenaar, 1998; Mitchell, 1973). In addition, field observation techniques assisted in cross checking predictions derived from models based on data obtained from measurements and secondary sources. Data used in include hydrological, hydrogeological, rainfall and well water data. Before the field data collection, a thorough study of the existing data and reports, a reconnaissance survey was carried out to have a complete understanding of site hydrogeology.

\subsection{Groundwater Flow Processes}

The Pwalugu floodplain wetland system constitutes a complex, three dimensional heterogeneous hydrogeological setting and does influences groundwater flow. Conceptually, the inflow pathways within the Pwalugu floodplain wetlands in the White Volta basin (Figure 1.3) differ both in the amount of water, which depend on their respective origin (rainfall, surface runoff, over bank flow and groundwater flow) and other processes (evapotranspiration) occurring within the system. Variation in inflowing water depends on morphological, hydrological-geological features and the landscape position of the wetland. As indicated in Figure 1.3 the flow pattern within the wetland is controlled by;

- thickness and physical parameters of the soil layer,

- occurrence of underlying aquifers, and

- occurrence of impermeable intercalated layers such as clay, silt or organic mud.

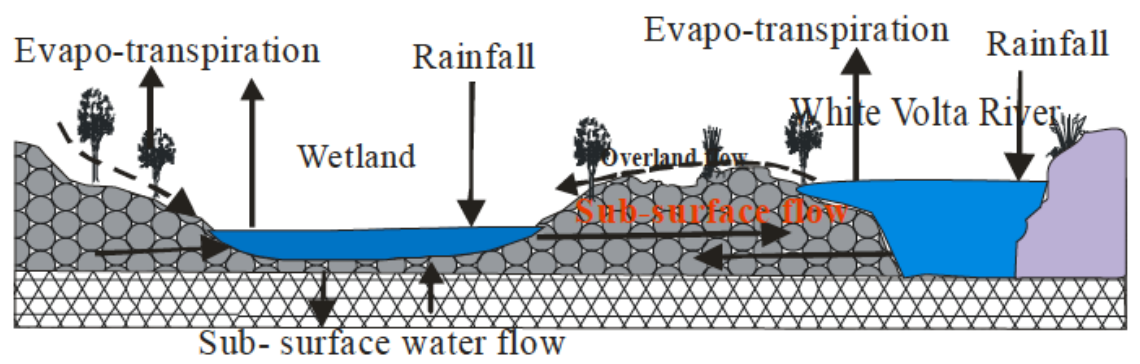

Figure 1.3. Conceptual diagram of floodplain wetland dynamics in the White Volta basin

Studying wetland water flow and interaction with river flow, the capabilities of representing groundwater flow as either steady state and/or transient state can be specified in the model. The steady state flow process does take place under the assumption that the magnitude and direction of flow is constant with time throughout the entire domain. Intransient flow, 
the magnitude and direction of the hydraulic head changes with time. In other words, the hydraulic head doesn't change with time in a steady state flow system, but does change during transient flow. Hence equation 1 the general form of the governing equation describes the three dimensional movement of groundwater at a constant density through any porous media (Freeze and Cherry, 1979):

$$
\frac{\partial}{\partial_{x i}}\left(K_{x i} \frac{\partial h}{\partial_{x i}}\right)+\frac{\partial}{\partial_{y i}}\left(K_{y i} \frac{\partial h}{\partial_{y i}}\right)+\frac{\partial}{\partial_{z i}}\left(K_{z i} \frac{\partial h}{\partial_{z i}}\right)-V_{f}=S s \frac{\partial h}{\partial t}
$$

Where: $K_{x i}, K_{y i}, K_{z i}$ are values of hydraulic conductivity along the $x i, y i$ and $z i$ coordinate axes $(\mathrm{L} / \mathrm{t}) ; h$ : is the potentiometric head (L); $V_{f}$ : is the volumetric flux per unit volume and represents sources and/or sinks of water per unit time $\left(\mathrm{t}^{-1}\right) ; S_{s}:$ is the specific storage of the porous material $\left(\mathrm{L}^{-1}\right)$; and $t$ : is time $(t)$.

The first part of equation (1) if run, to get a steady state solution takes the form as expressed in equation 2 :

$$
\frac{\partial}{\partial_{x i}}\left(K_{x i} \frac{\partial h}{\partial x i}\right)+\frac{\partial}{\partial_{y i}}\left(K_{y i} \frac{\partial h}{\partial y i}\right)+\frac{\partial}{\partial_{z i}}\left(K_{z i} \frac{\partial h}{\partial_{z i}}\right)-V_{f}=0.0
$$

From the steady state solution, the hydraulic conductivity for model aquifers can be found. Then the equations are solved for transient case in order to solve for storage coefficient.

\subsection{Model Setup}

The Pwalugu floodplain wetland site is represented by an array of rectangular cells, which embody the localized values of the aquifer characteristics (Figure 1.4). The area modeled covers $7.78 \mathrm{~km} 2$ and comprises 8648 square cells, out of which 5693 are marked as active cells. The model for the study site is represented in two layers, and the top of the uppermost layer (Figure 1.4) corresponds to the surface of the floodplain wetland; this layer can be dried and rewetted seasonally. The thickness of the top layer varies in thickness from $6.0 \mathrm{~m}$ when close to river and $26 \mathrm{~m}$ at the eastern boarder of the study site. The second layer below has a thickness of $10 \mathrm{~m}$, specified on the basis of a geological formation that limits storage and enhances transmission of water. This depends on the head gradient between the floodplain wetland and the river. The packages river, recharge and wetting capabilities were applied during the modeling process.

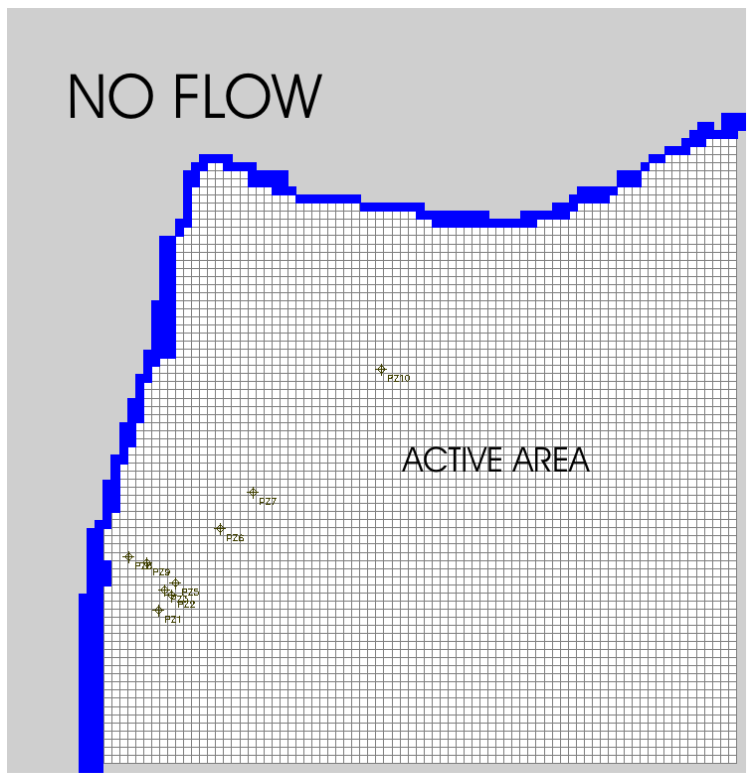

Figure 1.4. Setting of the Pwalugu floodplain wetland site

The river package (Prudic, 1989) was used to represent the White Volta River in the model. The White Volta River can gain from or contribute water to the floodplain wetland depending on the river stage (Figure 1.5), riverbed conductance and adjacent floodplain aquifer water levels. The Hydrological Service of Ghana measures the river surface elevation data. The low level of $133.05 \mathrm{~m}$ was recorded in January 2005, while September 2005 had the highest reading of $140.53 \mathrm{~m}$. 


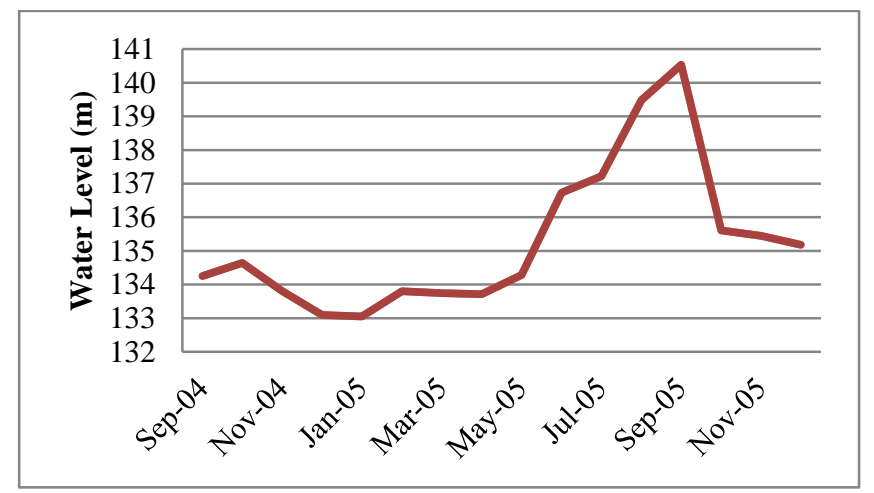

Figure 1.5. River gauge heights at Pwalugu Station

Riverbed conductance is a critical parameter in determining the amount of water seepage between the river and underlying aquifer (Hayashi and Rosenberry 2002). Conductance values of between $3.09 \times 104 \mathrm{~m} /$ day and $3.10 \mathrm{x}$ $104 \mathrm{~m} /$ day were assigned using the hydraulic conductivities of the observed changing bed materials consisting of alluvial deposits, metamorphosed sedimentary and granites outcrops that mostly from the riverbed. To simulate the lateral flow interaction between wetland and river, low permeability values was assigned to the riverbed to prevent leakage from the riverbed into the underlying aquifer.

The vertical and horizontal hydraulic conductivity with the floodplain wetlands are not uniform, but exhibit variability in terms of depth and direction. Two hydraulic conductivity layers were specified. Due to spatial heterogeneity of vertical hydraulic conductivity, a range of $0.012 \mathrm{~m} /$ day to $0.038 \mathrm{~m} /$ day was specified for the top layer. While a range of $0.12 \mathrm{~m} /$ day to $0.38 \mathrm{~m} /$ day was specified as the horizontal conductivity of the top layer. For the bottom layer, an arbitrary value of 0.09 $\mathrm{m} /$ day was specified for both vertical and horizontal hydraulic conductivities because of lack of information about the layer.

Recharge is limited to the behavior of the geological system that underlies the Pwalugu floodplain wetland site. This serves as a partitioning force that controls sub-surface recharge or water movement (Sanford 2002; Fox et al. 1998). As a boundary condition in the MODFLOW groundwater model, net bottom flux of HYDRUS-1D results was specifying as a recharge flux (figure 1.6). However, in the White Volta basin it is difficult to independently obtain an accurate recharge rate and distribution data. To estimate recharge for the Bongo granite aquifer in the Volta basin, Martin (2005) used the chloride mass balance, soil moisture balance and water table fluctuation methods. Martin (2005) obtained three different recharge values of $5.9 \%, 12.5 \%$ and $13 \%$ of the annual rainfall respectively. Apparently, recharge measurements in the field contain some amount of uncertainty; for the MODFLOW simulation, the bottom flux from the HYDRUS-1D model was specified as the net recharge (Figure 1.6) for the Pwalugu floodplain wetland. An estimated recharge of $444 \mathrm{~mm}$ for 16 months (487 days) obtained from HYDRUS-1D simulation served as an input into the model. It is important to stress here that the HYDRUS-1D bottom flux as the net recharge into the subsurface; in this case, water ponding and evapotranspiration has been accounted for.

\section{Calibration Criteria}

The PM-WIN model assisted to construct a two-dimensional transient model to quantify the temporal and spatial variation in the interaction between floodplain wetland and the White Volta River. The simulation of floodplain wetland and river flow interaction is important in estimating the flow and exchange of water between the wetland and river. An assumption made during the modeling process is that, conductivity of the riverbed is very low, thus any form of leakage from the river is a leakage into the wetland through the sub-surface. The model was run using both steady and transient mode.

To first calibrate the model parameters a steady state flow simulation was performed to obtain a tolerable distribution of initial hydraulic head. The vertical and horizontal hydraulic conductivity values of the top layer were adjusted to get good fit for conductivities of the layers. For the bottom layer, no value was set for both vertical and horizontal hydraulic conductivity, because the hydro-geological information was not available (Table 1.2). In addition, effective porosity, specific storage, storage coefficient and specific yield of the sub-surface were adjusted to fit the level of fluctuation occurring within the floodplain wetland. The adjustment of the conductivities and other parameters shifted the error of discrepancy between observed and modeled values to an appreciable level. 


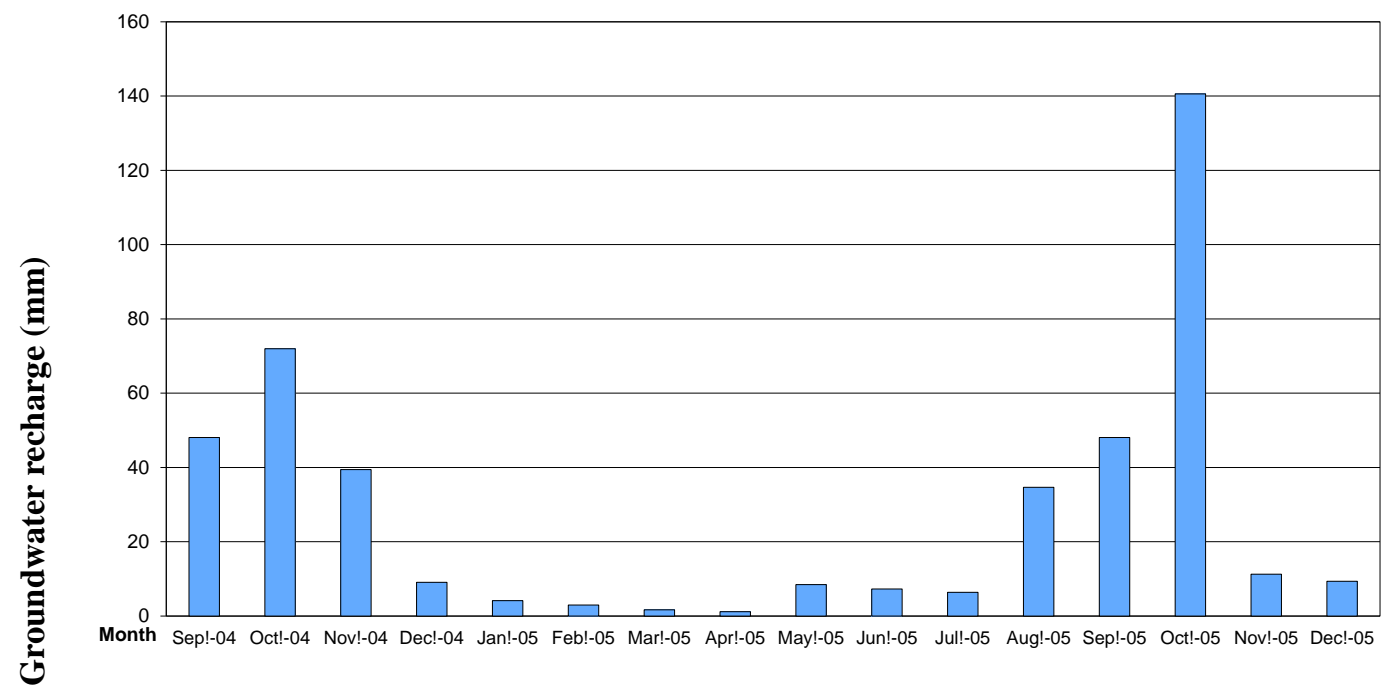

Figure 1.6. Monthly bottom fluxes from HYDRUS-1D

Table 1.2. Adjusted parameters for the PM-WIN model

\begin{tabular}{l|ll}
\hline & Top layer & Bottom layer \\
\hline Vertical conductivity & $0.12-0.38 \mathrm{~m} /$ day & $0.9 \mathrm{~m} /$ day \\
& $4 \mathrm{~m} /$ day & $0.09 \mathrm{~m} /$ day \\
Horizontal conductivity & $0.14-0.25$ & 0.25 \\
Effective porosity & 0.01 & 0.001 \\
Specific storage & $0.07 \mathrm{~m}^{3} /$ day & $0.001 \mathrm{~m}^{3} /$ day \\
Specific yield & 0.01 & 0.001 \\
\hline Storage coefficient &
\end{tabular}

In running the steady state model, the initial hydraulic head was assumed to be the interpolated hydraulic head of the piezometers and the river in September 2004. In addition, no recharge was specified; however an equilibrated head values as initial hydraulic head for steady and transient models. The adjustment proved to be optima for running the model. The period September to October 2004 was chosen for the calibration, as detailed hydraulic head measurements were available for the period.

The transient model was run in a time varying mode with daily time steps for 487 days.

\section{Sensitivity Analysis}

A sensitivity analysis is the process of varying model input parameters over a reasonable range (range of uncertainty in values of model parameters) and observing the relative change in model response. Studies have shown that in attempting to understand and measure any hydrological process, there are many different parameter sets within a chosen model structure that may be acceptable in reproducing the behaviour of that system (Feyen et al., 2004; Restrepo et al., 1998). There is seldom an "optimal" model that can generate simulated results at an acceptable limit of accuracy, rather it is more important to consider multiple possibilities for simulating in an acceptable range (Beven, 2001; Beven, 2009). To simulate results within an acceptable range, there should be sufficient interactions among components within the model. However, unless the detailed characteristics of these components can be isolated and calibrated independently, many representations may be equally acceptable. Consequently, searching for optimal parameter representation may not be possible, because it is statistically likely that the description of the system may be wrong. One justification for using multiple parameter sets to simulate a non-linear hydrological process stems from the fact that there are uncertainties associated with the use of models in prediction, because there are many acceptable model structures or acceptable parameter sets scattered throughout the parameter space (Beven 2009). Diekkrüger (2003) argued that nonlinear systems are particularly sensitive to their initial and boundary condition; hence any form of dynamics in these conditions may be important in controlling the observed response. It suggests that predictions of all acceptable models should include an assessment of prediction uncertainty. Uncertainty in hydrological models stem from the fact that they are not the true reflection of the processes involved, because condition and data for running the models are not error free. Hence, there is a need to find optimum parameters that are efficient and sensitive parameters to model (Beven, 2009; Hill, 1989).

Sensitivity analysis is performed when initial parameterization is complete in order to quantify relative changes in model output in response to changes in input parameter values. This process was carried out after model had been specified, and 
its benefits include: 1) a check on the model logic and robustness of the simulation, 2) identification of the importance of specific model parameters and corresponding effort that must be invested in data acquisition for different parameters. Dimensionless and dimension scaled are the two main types of sensitivity analysis performed in MODFLOWP. These types of sensitivity analysis mentioned above have been discussed in detail in the works of Hill (1998).

The main sources of uncertainty in modeling Pwalugu floodplain wetland site are the spatial distribution of the horizontal hydraulic conductivity, vertical hydraulic conductivity, specific storage and specific yield (Figure 1.7). While acknowledging the anisotropic nature of the aquifer deposits of the sub-surface deposit, however, anisotropy of horizontal hydraulic conductivity (HK_1), specific storage (SS_4) and specific yield (SY_3) were assumed at the scale of interest for the aquifer parameters. The implication is that uncertainty as a result of spatial variability of conductivity of the top layer is not accounted for in the present study. Van Leeuwen et al. (1999) showed that variability in vertical conductance of a confining clay layer strongly affects flow and shape of the capture zone. In the present study, variability is partly accounted for by the spatial variation of the thickness of the top layer.

Sensitivity analysis of horizontal hydraulic conductivity (HK_1), vertical hydraulic conductivity (VK_10), specific storage (SS_4) and specific yield (SY_3) determined which of the parameters had greatest effect on the simulated heads. MODFLOWP was used to generate sensitivities by perturbing the control parameters, during the simulation for 487 days on a daily time steps basis. The number of runs was 19 using 96 observations. Out of the 96 observations 30 had a residual greater or equal to zero, while the remaining 66 had residuals less than zero.

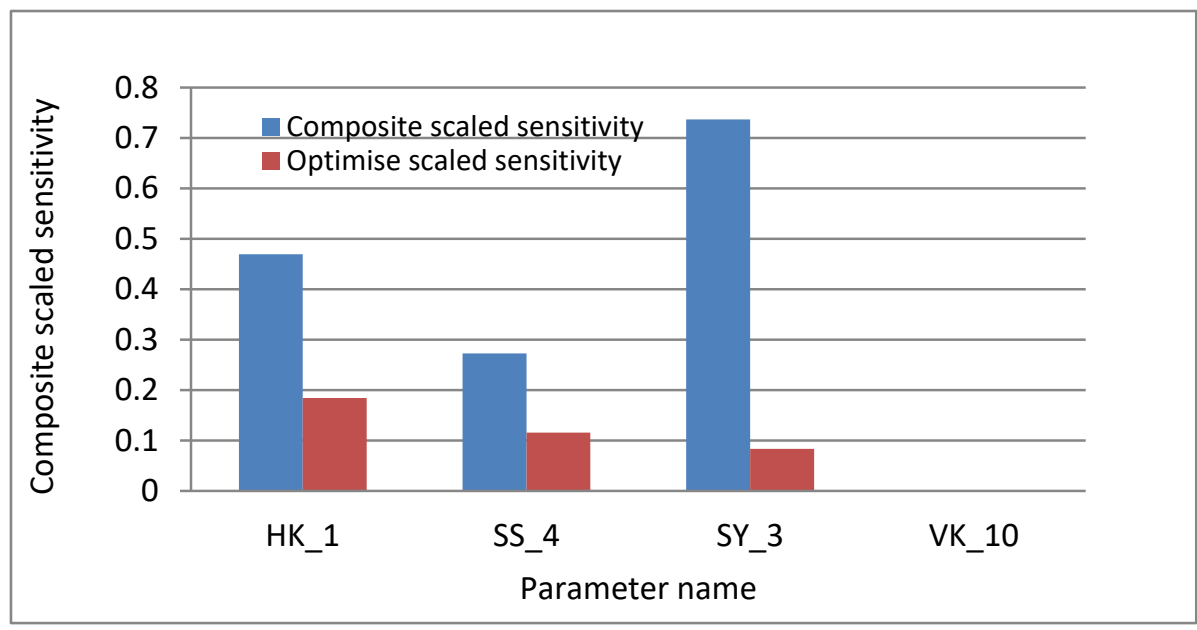

Figure 1.7. Composite scale sensitivity (horizontal hydraulic conductivity (HK_1), vertical hydraulic conductivity (VK_10), specific storage (SS_4) and specific yield (SY_3)

The composite-scaled sensitivity (Figure 1.7) indicates the relative importance of the sub-surface parameters used in the modeling processes. During the process of model calibration, HK_1, SS_4 and SY_3 were the parameters with a high level of sensitivity, thereby influencing the interaction process between floodplain wetland and White Volta River. VK_10 was insensitive to changes; hence it plays no role in the floodplain wetland-White Volta River flow interaction. After optimization, HK_1 was the most sensitive parameter, and any adjustment of HK_1 increased the amount of interaction between the wetland and the river.

\section{Boundary Conditions}

The recharge specified was the bottom flux obtained from HYDRUS-1D. Inflow and outflow at the model boundaries were varied between constant and variable head until the model results were in an acceptable range. The boundary conditions specified do not represent direct recharge, but are used in conjunction with recharge to realistically represent the sub-surface water system (Sanford 2002). The spatial limits of the geological formations provided no-flow boundaries to the north and west side of the river (Figure 1.4). Flow along the southern and eastern boundaries is specified as constant head. The model is specified to enable determination of whether the wetlands contribute to or receive water from the river. In running the model in the transient mode with wetting capabilities turned on, there was contribution of water flow from cells marked no-flow (inactive cells). In this situation, wetting capability was removed from the modeling process. Also, the bottom layer was disabled due to lack of data; hence it becomes a no flow boundary, thus only the top layer was used.

\section{Model Validation}

Results of calibration with the hydraulic conductivities and other parameters are shown in figure 1.8 as time discharge plot from six piezometers, for which the calculated head follows the pattern of the observed head. Water levels in the 
piezometers are always elevated in the rainy season and lower in the dry season, but PZ1 at the lowest point of the wetland is the last to dry. Data from piezometers in the Pwalugu floodplain wetland represented sections of the wetlands. The simulated curve generated shows a good fit with observations especially for PZ1, PZ2, PZ3, PZ5, PZ8 and PZ9. The rises in the hydraulic heads of the simulated hydrograph are similar and follow a pattern, while the observed hydraulic head shows some differences. The variability in the observed heads is likely to be a result of heterogeneity in the sub-surface aquifer structure.

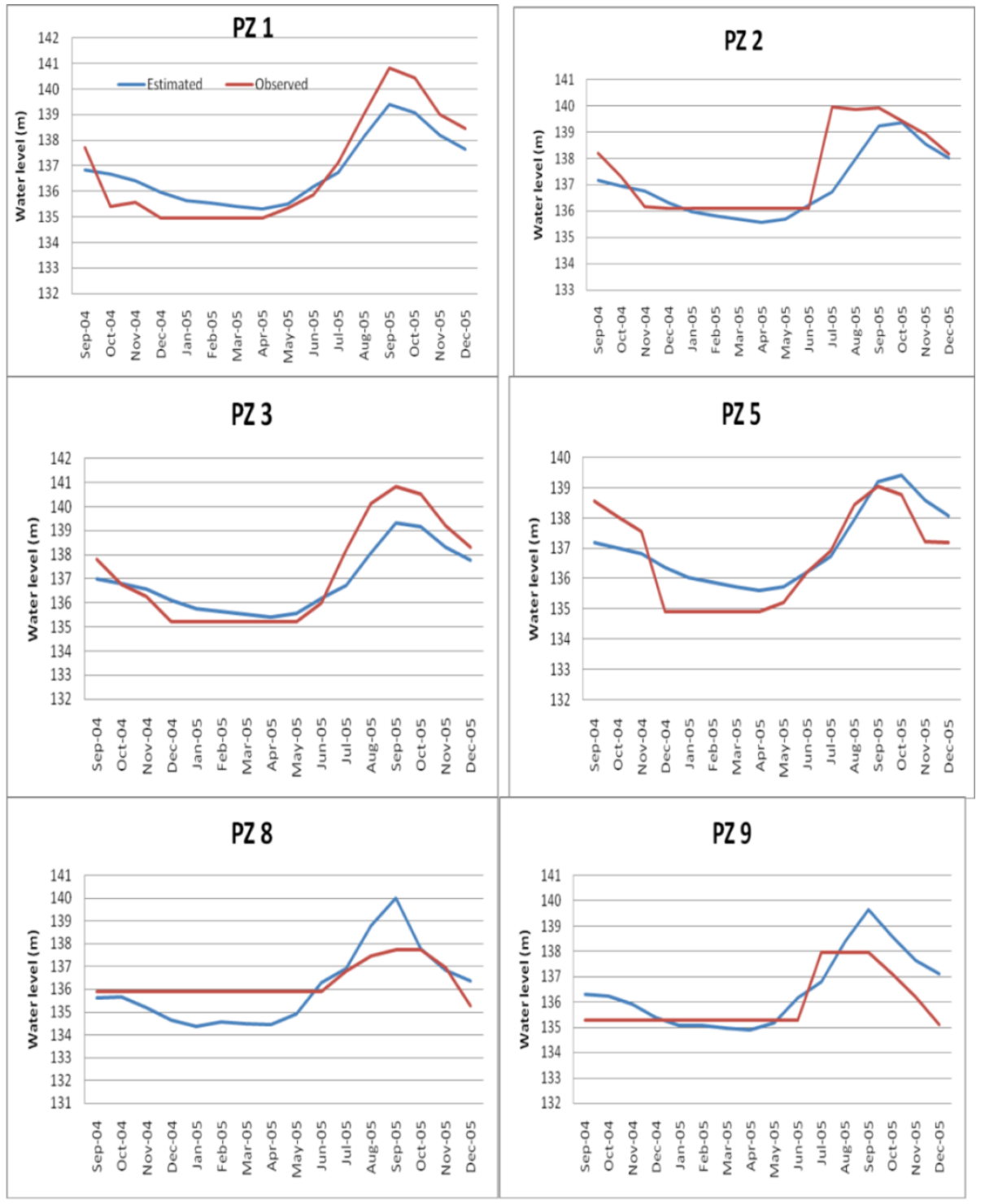

Figure 1.8. Simulated and observed heads in the Pwalugu floodplain wetland

\section{Floodplain Wetland and River Flow Interaction Modeling}

The simulation of sub-surface hydraulic head indicates a systematic variation relative to the White Volta River in response to changes in the rainfall pattern in the tropical savanna climatic zone. Over the months of September 2004, December 2004, March 2005, June 2005 and September 2005 (Figure 1.9) distinctive patterns of hydraulic heads were observed. For instance, the high hydraulic head simulated for September 2004 indicates that the floodplain wetland experienced a hydraulic head between $1 \mathrm{~m}$ and $3 \mathrm{~m}$ below the topographic surface. During August and September, a ponding height of $0.50 \mathrm{~m}$ was measured in the field. The heterogeneity of floodplain wetland topography makes ponding uneven. In June 2005, a comparatively high hydraulic head of 4 and $6 \mathrm{~m}$ is simulated below the topographic surface but close to the main river course, while the further away from the river, the deeper the hydraulic heads. A bi-direction of sub-surface water flow between the White Volta River channel and the floodplain wetland system is inferred as having a temporal and spatial variation. 
September 2004
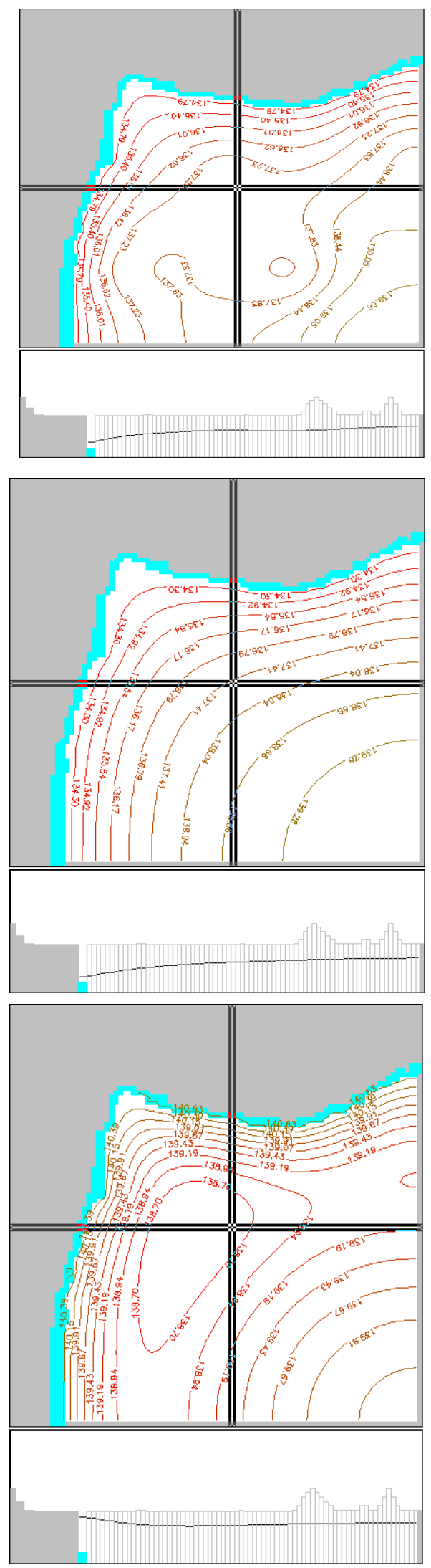

December 2004
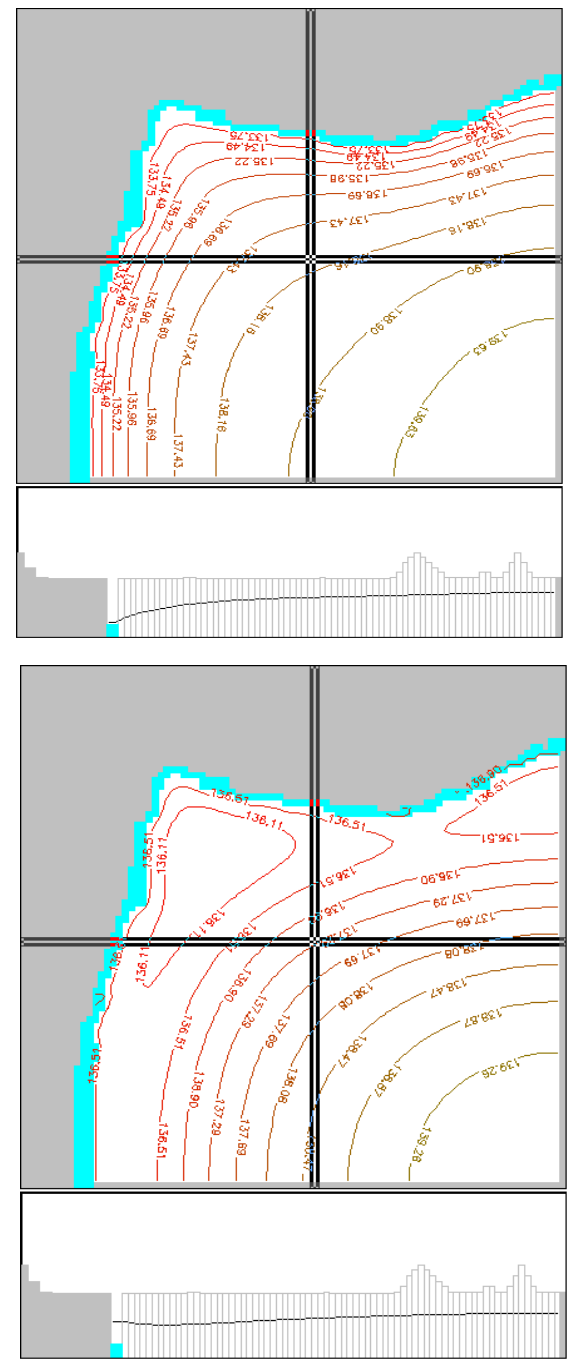

Figure 1.9. Depth of hydraulic head and cross section of floodplain wetland in September 2004, December 2004, March 2005, June 2005, and September 2005 
Figure 1.9 Depth of hydraulic head and cross section of floodplain wetland in September 2004, December 2004, March 2005, June 2005, and September 2005

December 2004

Table 1.3. Model fit statistics for the transient run monthly values of observed and simulated hydraulic heads

\begin{tabular}{r|c|c|c|c}
\hline ID & $\begin{array}{c}\text { Observed } \\
(\mathrm{m})\end{array}$ & $\begin{array}{c}\text { Simulated } \\
(\mathrm{m})\end{array}$ & $\begin{array}{c}\text { Root mean } \\
\text { square error } \\
\text { (RMSE) }\end{array}$ & $\begin{array}{c}\text { Index of } \\
\text { Agreement } \\
(\mathrm{IA})\end{array}$ \\
\hline PZ1 & 136.85 & 136.79 & 0.52 & 0.82 \\
\hline PZ2 & 137.53 & 137.00 & 0.45 & 0.89 \\
\hline PZ3 & 137.19 & 136.87 & 0.49 & 0.98 \\
\hline PZ5 & 136.74 & 137.04 & 0.33 & 0.93 \\
\hline PZ8 & 136.30 & 136.04 & 0.97 & 0.75 \\
\hline PZ9 & 135.95 & 136.47 & 0.55 & 0.89 \\
\hline
\end{tabular}

The HYDRUS-1D bottom flux used as an input into the model resulted in a fit between the simulated hydraulic head and observed sub-surface water level fluctuation. A comparison of 6 piezometer observations and simulated hydraulic head showed some outliers with a variance of $1.62 \mathrm{~m}$ with a root mean square error (RMSE) of $1.28 \mathrm{~m}$. For instance, PZ1 and PZ3 indicated a $R^{2}$ of 0.93 between the observed and simulated hydraulic head (Figure 1.10). Level of compatibility indicates the need to improve model calibration. Individual piezometers in the wetlands showed differences between the observed and simulated head (Table 1.3). PZ-1 located within the wetland and about $300 \mathrm{~m}$ away from the White Volta River gave a better fit $(\mathrm{IA}=0.82, \mathrm{MAE}=0.72 \mathrm{~m}$ and $\mathrm{RMSE}=0.52 \mathrm{~m}) . \mathrm{PZ}-8$ in close proximity to the river shows a lower IA of 0.75 , and RMSE of $0.97 \mathrm{~m}$. Given the lack of spatial data, e.g., local flow pattern and hydraulic properties with depth, accurate calibration will not be feasible. Therefore, detailed data on variation in the landscape, sub-surface water level fluctuation and bottom discharge is required to develop a validated model for management of floodplain wetlands in the White Volta basin.

The mass balance (Table 1.4) accounted for the sources of water for recharge or discharge of a hydrologic system on monthly basis. The cumulative mass balance at the end of the run period of 16 months ( 487 days) for the transient model demonstrate the importance of recharge as a water balance input. The monthly recharge generated suggests a significant contribution of water from wetlands into the river. At sites that do not have any form of sub-surface influence, the form of interaction between the wetland and the White Volta River resulted from overbank flow. Another important process is backwater effect, which contributes to extensive ponding leading to surface water storage as noted in the Tindama floodplain wetland.

The interaction conditions vary from season to season, with March, April and May showing the lowest leakage of 0.03 $\mathrm{mm} /$ day, $0.06 \mathrm{~mm} /$ day and $0.15 \mathrm{~mm} /$ day respectively, from the river into the floodplain, although the expectation is that floodplain wetland serves as a moisture buffer and supplies the river with water during the low season. However, period between July and September 2005, the recharge of floodplain wetland aquifer caused an increase in the volume of water storage in the wetlands from $992793 \mathrm{~m}^{3}$ to $1404853 \mathrm{~m}^{3}$. Interaction between the wetland and river is bidirectional, with most of the flow coming out from the river (Table 1.4), a condition that persisted in August and September. The leakage contribution of floodplain wetland to the river in August was $97.28 \mathrm{~mm}$, increasing to $172 \mathrm{~mm}$ in November as rainfall reduced. In 2005, contribution of floodplain wetland to the river was $86.01 \mathrm{~mm}$, while the river contributed $131.63 \mathrm{~mm}$. The period from September 2004 to December 2005, a total simulated recharge of $444 \mathrm{~mm}$ from HYDRUS-1D applied to the wetland system, out of which $169.21 \mathrm{~mm}$ leaked into the wetland from the river. Conversely, a total of $215.03 \mathrm{~mm}$ leaked out of the wetland system to contribute to the sustenance of the White Volta River. In this situation, floodplain wetland contributes as base flow to the White Volta River in the dry season. The total amount of water $556.75 \mathrm{~mm}$ moving out of the storage in the 16 month period is only for the simulation period, and becomes depleted during the dry season. The full cycle of the dynamics of hydraulic head simulation to indicate floodplain wetland and the White Volta River 


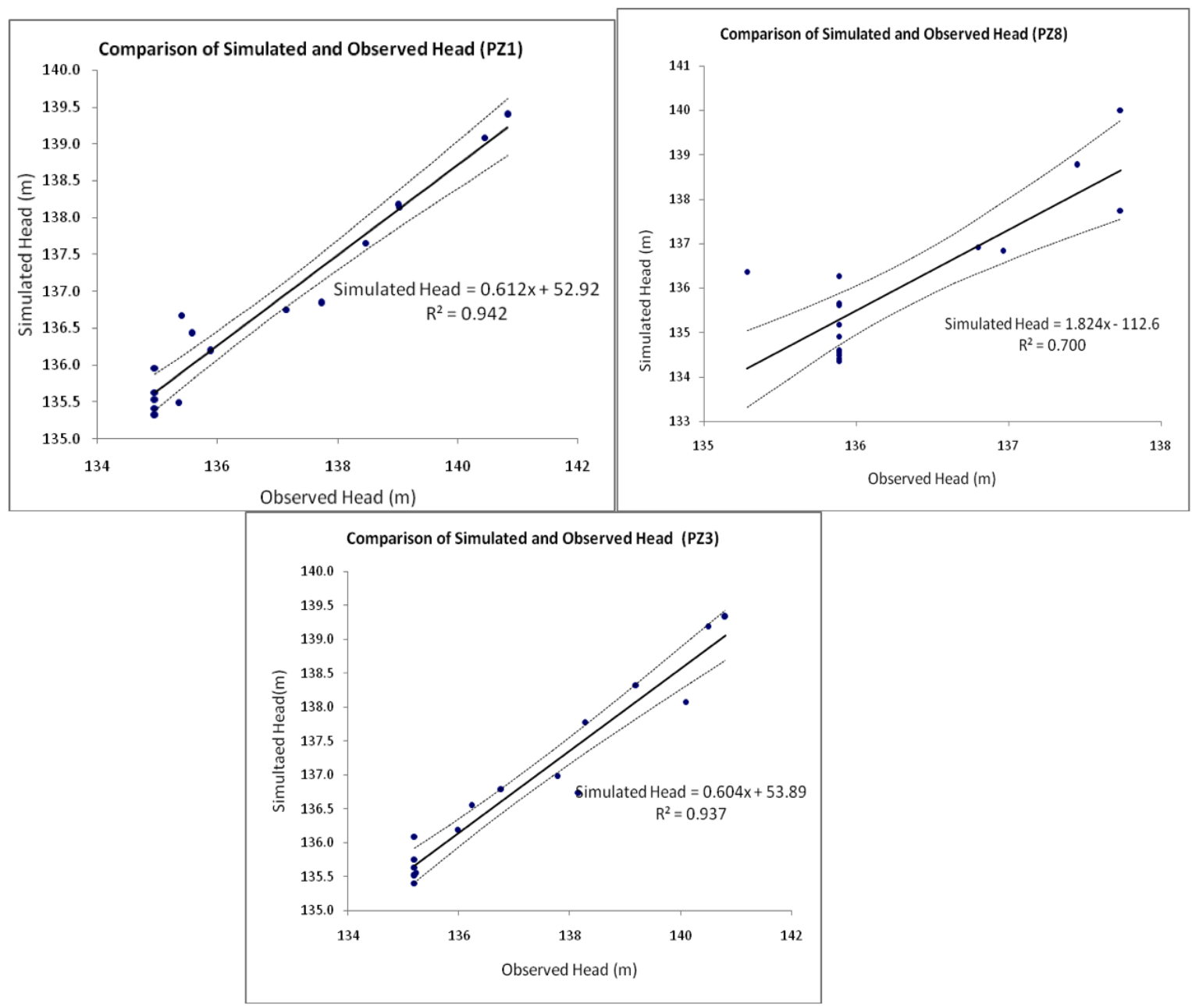

Figure 1.10. Comparison of simulated and observed heads in the Pwalugu floodplain wetland for a period of 16 months (September 2004 to December 2005). The dotted lines indicate 95\% confidence interval interaction from September 2004 to December 2009 is show in (Figure 1.9).

Table 1.4. Cumulative mass balance

\begin{tabular}{l|rcc}
\hline & \multicolumn{1}{|c}{2004} & 2005 & Sept. 2004-Dec.2005 \\
\hline IN: & \multicolumn{1}{c}{$\mathrm{mm}$} & $\mathrm{mm}$ & $\mathrm{mm}$ \\
Storage & 36.23 & 61.76 & 171.87 \\
River leakage & 2.31 & 131.63 & 169.21 \\
Recharge & 159.67 & 221.11 & 421.64 \\
Total In & 198.21 & 414.50 & 762.72 \\
OUT: & & & \\
Storage & 141.33 & 338.57 & 556.75 \\
River leakage & 58.91 & 86.01 & 215.03 \\
Total out & 200.24 & 424.58 & 771.78 \\
In - Out & -2.03 & -10.07 & -9.06 \\
\hline
\end{tabular}

During the rainy season between June and September 2005, the hydraulic head in the Pwalugu floodplain wetlands increased from an average of $137.79 \mathrm{~m}$ to $139.43 \mathrm{~m}$, but started declining from October 2005 where the hydraulic head was $138.38 \mathrm{~m}$. The extent, depth, frequency, timing and duration of water ponding at the surface of the wetlands are important parameters controlling the extent of soil moisture for the sustenance of the river. For instance, ponded water in 
the Pwalugu wetland to a depth of $0.50 \mathrm{~m}$ measured during fieldwork in August 2005 results from a complex and variable combination of groundwater upwelling and accumulation of rainfall on the saturated surface. Saturation of the entire wetland was rarely achieved in 2004, because of frequent breaks in rainfall pattern with longer dry spells. In addition, the geological formation within the study area is Voltaian sandstone. The formation is a poor water retention system, and water stored during the rainy season is not readily transmitted to other parts of the system. Connectivity is not a fixed characteristic of a system, but rather varies over space and time (Leibowitz, 2003; Leibowitz and Vining, 2003). Variability in hydrologic connectivity results primarily from the longitudinal expansion and contraction of the river network and transient connection with other components of the river system.

The internal conceptualization of Pwalugu floodplain wetland is based on a semi-confined one-layer system with differing hydraulic characteristics. However, the interaction between the White Volta River and floodplain wetlands takes place in one of these three basic ways: 1) rivers gain water from inflow of groundwater through the riverbed, 2) river lose water to groundwater by outflow through the riverbed or both, or 3) river gain in some reaches and lose in others. The manner of interaction between the Pwalugu floodplain wetland and the White Volta River depends upon the processes controlling the recharge, floodplain morphology and hydraulic properties of the system. In this setup, the amount of water delivered to the water table is controlled by the geological formation. Another issue of concern is the estimation of spatial distribution of recharge, and this can only be estimated if accurate information on the magnitude and distribution of aquifer properties is available. More over, during the low flows after hydrologic events, the water stored in these alluvial aquifers can serve as another source of baseflow in rivers

\section{Conclusions}

The hydrology of the wetlands found in the basin is complex characterized by spatial and temporal variability of their volume and surface area. The White Volta River catchment is experiencing climatic, hydrologic and vegetation changes. To ensure good management and a sustainable level of water resource usage, this research was conducted to examine the essential role floodplain-wetlands play in stream flow within the White Volta basin. This research shows that changes in floodplain-wetland characteristics have ramifications on surface water flow. Data collected for the study were derived from field measurements, field observation and laboratory analysis.

The hydraulic connection between the White Volta River and floodplain wetland varies temporally and spatially because of intervening unsaturated zones. To establish the form of interaction that goes on between the main river and floodplain wetlands within the White Volta basin, PM-WIN(MODFLOW) was specified using lower boundary discharge from the HYDRUS-1D model as estimated groundwater recharge. This input quantifies the temporal and spatial variations in the interaction between floodplain wetland and stream flow. Prior to simulation, parameters were calibrated to obtain a tolerable distribution of initial hydraulic head. The calibration process reduced the error of discrepancy from -0.69 to 0 . The HYDRUS-1D bottom flux used as an estimate of groundwater recharge gave a better fit between the simulated hydraulic head and observed sub-surface water level fluctuation. This level of compatibility gives indications that the model calibration needs to be improved.

The simulation of the sub-surface hydraulic head of the wetland indicates a systematic variation relative to the White Volta River in response to changes in the rainfall pattern. More also, within hydrologic landscape, permeability of soil and geologic formation are also important determinants of hydrologic flowpaths. Permeable soils promote infiltration that results in groundwater hydrologic flowpaths, whereas the presence of impermeable soils with low infiltration capacities is conducive to overland flow. These local groundwater flowpaths connect portions of watersheds to nearby wetlands or streams. Alternatively, if a deep permeable geologic material (an aquifer) is present, water is likely to move further downward within watersheds and recharge deeper aquifer. The permeability of soils and geologic formations can both influence the range of hydrologic connectivity between unidirectional wetlands and river networks.

The interaction conditions vary from season to season with March, April, and May showing the least leakage (estimated values of $0.03 \mathrm{~mm} /$ day, $0.06 \mathrm{~mm} /$ day and $0.15 \mathrm{~mm} /$ day, respectively) from the river into the floodplain, although the expectation is that floodplain wetlands serve as a moisture buffer and supply the river with water during the low season. Nevertheless, the interaction between the wetland and the river as simulated is bidirectional. With most of the flow coming out from the river, this condition persists in the months of August and September.

\section{Acknowledgements}

The authors are grateful to the many field assistants who helped with the collection of data.

\section{Disclosure statement}

No potential conflict of interest was reported by the authors. 


\section{Funding}

The work presented is part of the $\mathrm{PhD}$ research work of the first author, which was funded by the German Ministry of Education and Research (BMBF), the GLOWA-Volta Project, and the Centre for Development Research (ZEF), Germany.

\section{Reference}

Acheampong, S. Y., \& Hess, J. W. (1998). Hydrogeologic and hydrochemical ramework of the shallow groundwater system in the southern Voltaian Sedimentary Basin of Ghana. Hydrogeol J, 6(4), 527-537. https://doi.org/10.1007/s100400050173

Beven, J. K. (2000). Rainfall-Runoff Modelling: The Premier, John Wiley \& Sons Ltd. U.K.

Beven, K. J. (1978). The hydrological response of headwater and slideslopes areas. Hydrological Sciences Bulletin, 23, 419-437. https://doi.org/10.1080/02626667809491821

Beven, K. J. (1989). Changing ideas I hydrology- the case of physically based models. J Hydrol, 105, $157-172$. https://doi.org/10.1016/0022-1694(89)90101-7

Beven, K. J., Wood, E. F., \& Murugesu, S. (1988). On hydrological heterogeneity-Catchment morphology and catchment response. J Hydrol, 100, 353-375. https://doi.org/10.1016/0022-1694(88)90192-8

Bockelmann, B. N., Fenrich, E. K., Lin, B., \& Falconer, R. A. (2004) Development of an ecohydraulics model for stream and river restoration. Ecological Engineering, 22(4-5), 227-235. https://doi.org/10.1016/j.ecoleng.2004.04.003

Bonell, M., \& Balek, J. (1993). Recent Scientific Development and Research Needs in Hydrological Processes of Humid tropics: 167-260. In: Bonell M, Hufschmidt MM, Gladwell JS (eds) Hydrology and water management in the humid Tropics: Hydrological research issues and strategies for water management. Cambridge University Press, Great Britain. https://doi.org/10.1017/CBO9780511564468.015

Brian, W. J. (1962). Agriculture and Land Use in Ghana. OVP.

Brooks, R. T. (2005). A review of basin morphology and pool hydrology of isolated ponded wetlands: Implications for seasonal forest pools of the northeastern United States. Wetlands Ecology and Management, 13, 335-348. https://doi.org/10.1007/s11273-004-7526-5

Chiang, W. H., \& Kinzelbach, W. (1998). Processing Modflow. A simulation program for modelling groundwater flow and pollution. User manual.

Cloke, H. L., Anderson, M. G., McDonnell, J. J., \& Renaud, J. P. (2006). Using numerical modelling to evaluate the capillary fringe groundwater ridging hypothesis of streamflow generation. Journal of Hydrology, 316(1-4), 141-162. https://doi.org/10.1016/j.jhydrol.2005.04.017

Diekkrüger, B. (2003). Models-calibration, validation, sensitivity analysis (I and II). Presentation at Bonn. Retrieved from http://www. giub. uni-bonn. de/hrg/Poster. htm

Dingman, L. S. (2002). Physical Hydrology, Prentice Hall, New Jersey, USA.

Dixon, M. J. R., Loh, J., Davidson, N. C., Beltrame, C., Freeman, R., \& Walpole, M. (2016). Tracking global change in ecosystem area: the Wetland Extent Trends index. Biological Conservation, 193, $27-35$. https://doi.org/10.1016/j.biocon.2015.10.023

Domenico, P. A. (1972). Concepts and Models in Groundwater Hydrology, McGraw-Hill, New York

Fernald, A. G., Wigington Jr, P. J., \& Landers, D. H. (2001). Transient storage and hyporheic flow along the Willamette River, Oregon: Field measurements and model estimates. Water Resources Research, 37(6), 1681-1694. https://doi.org/10.1029/2000WR900338

Feyen, L., Dessalegn, A. M., De Smedt, F., Gebremeskel, S., \& Batelaan, O. (2004). Application of a Bayesian approach to stochastic delineation of capture zones. Groundwater, 42(4), 542-551. https://doi.org/10.1111/j.1745-6584.2004.tb02623.x

Fischer-Antze, T., Stoesser, T., Bates, P., \& Olsen, N. R. B. (2001). 3D numerical modelling of open-channel flow with submerged vegetation. Journal of Hydraulic Research, 39(3), 303-310. https://doi.org/10.1080/00221680109499833

Grapes, T. R., Bradley, C., \& Petts, G. E. (2006). Hydrodynamics of floodplain wetlands in a chalk catchment: The River Lambourn, UK. Journal of Hydrology, 320(3-4), 324-341. https://doi.org/10.1016/j.jhydrol.2005.07.028 
Hayashi, M., \& Rosenberry, D. O. (2002). Effects of ground water exchange on the hydrology and ecology of surface water. Groundwater, 40(3), 309-316. https://doi.org/10.1111/j.1745-6584.2002.tb02659.x

Hill, M. C. (1998) Methods and guidelines for effective model calibration: U.S. Geological Survey Water-Resources Investigations Report 98-4005, 90 p. [with application to UCODE, a computer code for universal inverse modeling, and MODFLOWP, a computer code for inverse modeling with MODFLOW

Jung, J. (2006) Regional Climate Change and the Impact on Hydrology in the Volta Basin of West Africa PhD thesis, Garmisch-Partenkirchen, Institut f'ur Meteorologie und Klimaforschung Bereich Atmosph"arische Umweltforschung (IMK-IFU) Forschungszentrum Karlsruhe in der Helmholtz-Gemeinschaft

Lang, M., McDonough, O., McCarty, G., Oesterling, R., \& Wilen, B. (2012). Enhanced detection of wetland-stream connectivity using LiDAR. Wetlands, 32(3), 461-473. https://doi.org/10.1007/s13157-012-0279-7

Martin, N. (2006). Development of a water balance for the Atankwidi catchment, West Africa: A case study of groundwater recharge in a semi-arid climate. Cuvillier.

Matos, J. E., Welty, C., \& Packman, A. I. (2002, December). Stream-Groundwater Interactions and Near-Stream Flow Systems: The Influence of Aquifer Heterogeneity and Stream Meandering on Three-dimensional Hyporheic Exchange Flows. In AGU Fall Meeting Abstracts.

Nield, S. P., Townley, L. R., \& Barr, A. D. (1994). A framework for quantitative analysis of surface water-groundwater interaction: Flow geometry in a vertical section. Water Resources Research, 30(8), 2461-2475. https://doi.org/10.1029/94WR00796

Prudic, D. E. (1989). Documentation of a computer program to simulate stream-aquifer relations using a modular, finite-difference, ground-water flow model. https://doi.org/10.3133/ofr88729

Reid, M. A., \& Quinn, G. P. (2004). Hydrologic regime and macrophyte assemblages in temporary floodplain wetlands: implications for detecting responses to environmental water allocations. Wetlands, 24(3), 586. https://doi.org/10.1672/0277-5212(2004)024[0586:HRAMAI]2.0.CO;2

Restrepo, J. I., Montoya, A. M., \& Obeysekera, J. (1998). A wetland simulation module for the MODFLOW ground water model. Groundwater, 36(5), 764-770. https://doi.org/10.1111/j.1745-6584.1998.tb02193.x

Sanford, W. (2002). Recharge and groundwater models: an overview. Hydrogeology Journal, 10(1), 110-120. https://doi.org/10.1007/s10040-001-0173-5

Schot, P. P., \& Winter, T. C. (2006). Groundwater-surface water interactions in wetlands for integrated water resources management (preface). Journal of Hydrology, 320(3-4), 261-263. https://doi.org/10.1016/j.jhydrol.2005.07.021

USEPA (US Environmental Protection Agency). (2015). Connectivity of streams and wetlands to downstream waters: a review and synthesis of the scientific evidence.

Woessner, W. W. (2000). Stream and fluvial plain ground water interactions: rescaling hydrogeologic thought. Groundwater, 38(3), 423-429. https://doi.org/10.1111/j.1745-6584.2000.tb00228.x

Wu, W., Rodi, W., \& Wenka, T. (2000). 3D numerical modeling of flow and sediment transport in open channels. Journal of hydraulic engineering, 126(1), 4-15. https://doi.org/10.1061/(ASCE)0733-9429(2000)126:1(4)

\section{Copyrights}

Copyright for this article is retained by the author(s), with first publication rights granted to the journal.

This is an open-access article distributed under the terms and conditions of the Creative Commons Attribution license (http://creativecommons.org/licenses/by/4.0/). 